\title{
DEFYING ABSOLUTES AND ESSENTIALISM IN DEREK WALCOTT'S OMEROS: AN EPIC OF TRACES
}

\author{
EL DESAFÍO AL ESENCIALISMO Y LO ABSOLUTO \\ EN OMEROS, DE DEREK WALCOTT: \\ UNA ÉPICA DE TRAZAS
}

MÓNICA FERNÁNDEZ JIMÉNEZ

Universidad de Valladolid

monica.fernandez@uva.es

\begin{abstract}
Using poststructuralist and postmodern theory, this article analyses the postcolonial epic poem Omeros (1990) by the author Derek Walcott. In using such a genre, Derek Walcott opens up a discussion on the literary canon and the role of epics. The authority of canonical genres is established through the use of some of the epic's formal conventions in order to be subsequently questioned through the subversion of some others relating to register and perspective. In this way, Walcott establishes a poststructuralist approach to identity which is perceived as fluid, heterogeneous, and subject to transformations. The intertextuality and parody at work in the text bring to light postmodern concerns about history and the past, which are presented as non-absolute traces. In the end, the epic recovery of roots becomes in this poem an invocation of anti-essentialism.
\end{abstract}

Keywords: epic, postmodernism, intertextuality, poststructuralism, postcoloniality.

\section{Resumen}

Este artículo analiza el poema épico poscolonial Omeros (1990), del autor Derek Walcott, haciendo uso de teoría posestructuralista y posmoderna. Al utilizar este género, Derek Walcott evoca un debate más amplio respecto al canon literario y al 
papel de las épicas. Establecer esta autoridad sirve para más tarde cuestionarla al subvertir la forma, registro y perspectiva tradicionales del género. De esta manera, Walcott afirma una visión posestructuralista de la identidad percibida como fluida, heterogénea y sujeta a transformaciones. La intertextualidad y parodia empleadas en la obra acercan preocupaciones sobre la historia y el pasado, que son presentados como trazas no absolutas. En definitiva, la recuperación épica de las raíces es en el poema una invocación de antiesencialismo.

Palabras clave: épica, posmodernismo, intertextualidad, posestructuralismo, poscolonialidad.

By analysing through poststructuralist and postmodernist lenses the long epic poem Omeros (1990), written by the 1992 Nobel Prize winner Derek Walcott, this article attempts to show that his subversive use of the epic genre makes a statement about the non-essentialist state of affairs of postcolonial cultures, cultural productions, and identity, especially those of the Caribbean. According to Walcott, the Caribbean is shaped by the influence of distinct coexisting cultures, but also by the recovery of those that were lost in violence and, as he expresses it, by "the restoration of our shattered histories" (1998: 69). Transformation, mobility, and fluidity are, in Walcott's view, characteristic of Caribbean cultural identity. The epic, a genre apparently fossilised, narrates the absolute past according to Mikhail Bakhtin (1981), and is linked to the emergence of new nations, and to the foundation of civilisations (Hamner 1997). However, due to its colonial history, the Caribbean does not have one foundational moment; it is a region that is culturally diverse and in constant motion as a result of the decimation of the native population, the forced displacement of African slaves with its consequent cultural loss, the presence of creole settlers, and the migration which Elleke Boehmer points out as characteristic of once-colonised peoples after the 1980s (1995: 233). By writing this epic, Walcott does not tell the story of how certain travellers settled in a place and founded a new civilisation there. Travel itself is the founding.

The emphasis on fluidity, mobility, and anti-essentialism conveyed by Walcott's epic denotes a poststructuralist approach to history which defies essentialist positions embodied both in the staticity of colonialism and in the historical role of epics. As Boehmer claims, after the 1980s, because of their similar views on anti-essentialism, Postcolonial Studies and Western Poststructuralism begin to converge (1995: 223). These schools of thought show a similarity in their conceptual reconsideration of the structures that restricted worldviews and 
"unequal relations of power" have created (Gikandi 2006: 97). A mention of Postmodernism is also necessary for these analyses, especially in its rejection of grand totalising narratives like history (Hutcheon 1988: 12). Thomas Byers claims that "postmodernity is the dominant socio-cultural condition of the most economically and technologically developed countries and regions, most notably the USA, Western Europe, and Japan" (2011: 11). However, I argue in this article that responses to postmodernity can be located within the postcolonial settings he excludes, since Omeros considers a hemispheric approach to the Americas, according to which the United States and the Caribbean are constantly influencing each other through tourism, migration, and globalisation.

Furthermore, it is interesting to problematise the relationship between Postmodernism and Postcolonialism. The writer bell hooks worries "that the postmodern call to dismantle identity comes at a historical moment when subjugated peoples are beginning to assert their own identity and to act collectively in its name" (2001: 2508). However, hooks's claim does not translate into a rejection of Postmodernism; it is rather a call for non-white intellectuals to articulate and embrace its poetics of difference and "incorporate the voices of the displaced, marginalized, exploited, and oppressed black people" (2511). Postcolonial writing lends itself to postmodern theory because of its emphasis on "the constructed nature of identity" (Boehmer 1995: 244). According to Linda Hutcheon's thoughts on historiographic metafiction, postmodernist art "has acknowledged [its] ideological positioning in the world" (1988: 179) and therefore aimed at contesting centred positions such as a Western worldview. Walcott's metafictional elements are visible through the pages of Omeros - "a poem about writing about the Caribbean", according to Paul Jay (2006: 546) - as well as his belief expressed in the poem LII of the collection Midsummer that "No language is neutral" (Walcott 2014: 361). In fact, as Hutcheon states while referring to Robertson's concept of 'game playing', instead of underplaying the relevance of history and fact, postmodern accounts "rather politicize them through their metafictional rethinking of the epistemological and ontological relations between history and fiction" (1988: 121).

I will thus view Walcott's epic through two main theoretical lenses. First of all, Omeros will be considered an epic of poststructuralist Derridean traces following Stuart Hall's approach to identity as being fluid, not an essence. I will argue that the poststructuralist approach, with its concept of meaning as transformable, is particularly suited to an analysis of Walcott's subversion and parody of the epic genre. Secondly, I will analyse Omeros's take on the past as transformable, aligning first with Derridean thought to examine a particular chapter of the epic and second with Linda Hutcheon's ideas on Postmodernism as a tool of resistance for the 
"silenced ex-centrics" (1988: 179), with its intertextuality bringing awareness of the textually constructed nature of history and the past (for which she also uses the word traces). Many elements in Omeros lead to the conclusion that the poem is indeed a postmodern work. I will conclude that the poem's epic recovery of the lost homeland establishes such place as an absence, not a presence, thus rejecting the fossilisation of the colonial conceptions of home, roots, and memory as central to the creation of a stable cultural identity.

\section{The Poststructuralist Approach to the Epic Genre: A Postcolonial Device}

According to Simon Gikandi, the emergence of Postcolonial Studies in the 1970s would not have been possible without the previous emergence of Poststructuralism (2006). As Ania Loomba points out, the poststructuralist approach to history affirms that there is not a single history but many histories, and that this is the only way for formerly colonised peoples' lives to be articulated and represented (1998). Poststructuralism teaches that interpretation and meaning are transformable, so it becomes a tool for subalterns to explore the (hi)story which they had been denied (Prakash 1994), without turning it into an absolute truth - even a grand narrative-, one of the main concerns in Omeros. In this section I will explore how, through taking an apparently fossilized genre according to Hegel (Domínguez Caparrós 2009: 164), and subverting its conventions in the transformable fashion proposed by Poststructuralism, Omeros stands for the articulation of a postcolonial cultural identity devoid of essentialism.

Through the imagery of sea travellers and the use of the epic genre, Walcott adopts this poststructuralist perspective in analysing Caribbean cultural identity. Joseph Farrell's defence of Walcott's use of the epic by claiming that the genre is not a Western property but also present in non-Western traditions (1997) does not deny the fact that it is a genre that tries to connect with roots, something which becomes problematic in the Caribbean. According to Haleh Zargarzadeh, cultural identity markers like homecoming and roots cannot work with the same parameters within the context of the Caribbean (2017: 716). Thus Walcott, like Édouard Glissant in his Poetics of Relation, establishes a rhizomatic approach towards history and identity, and also towards genre, not adhering to all the conventions of the epic but subverting them. If we follow poststructuralist critique, using the epic genre is not the ambiguous act of engaging with the tradition of white imperialism that Farrell problematises (1997). Rather, it can be understood as postmodern mimicry, as Rei Terada puts it (1992), an assessment of the act of writing as Deleuzian repetition, always entailing difference (Deleuze 1968). Through a process of 
self-discovery and exploration in the shape of sea voyages, Omeros's characters realise that identity - like history - does not consist of something fossilised like a ruin but is rather formed by Derridean traces and Deleuzian repetition, more in accordance with the renewal and fluidity of the sea that surrounds their island.

We learn from Farrell (1997: 272) that many critics do not consider Omeros an epic, which the author also allegedly believes (Hamner 1997: 33; McGarrity 2015: 10). However, the poem resembles the traditional genre of the epic formally and thematically. It uses hexameters —although not regularly (Callahan 2003: 13) and terza rima (McGarrity 2015: 9); it is long and narrative in form; it presents a catalogue of boats in chapter two, reminiscent of The Iliad (27), and an invocation to the muses in chapter sixty-four; it includes chapters dealing with the actions of gods affecting the fate of the characters, especially in Book III with Achille's journey to Africa, and even a descent to the underworld in chapter fifty-two. In addition, it addresses the fate of a people, race, or nation, as is characteristic of the epic (Toohey 1992; Tynan 2011). On the other side of the coin, the order in which this is done is inverted. Instead of following the journey of a hero towards his new home, as The Aeneid does, it is a conscious journey of recovery of what has been lost for the Caribbean people. It also inverts the traditional epic structure in announcing its hero - anti-hero in this case - at the end of the poem (Farrell 1997: 281): "I sang of quiet Achille, Afolabe's son" (Walcott 1990: 320).

Furthermore, Omeros breaks with every philosophical conception of the epic. While Lukács describes the epic world as homogeneous (1971: 32), Walcott presents a heterogeneous culture. In addition, Bakhtin argues that the epic has the absolute past as its object (1981: 13), but the postmodern, postcolonial, and poststructuralist vision that permeates Walcott's work rejects the very idea of the existence of an absolute past (Derrida 1997: 67). As exposed in Lukács's Theory of the Novel, in the times when the epic was possible,

the members of a particular historical community [were] able to recognize themselves in the ethical world portrayed in the epic poem because this world constitute[d] an adequate presentation of the ethical relations that form[ed] this community's essence and determine[d] its members' thoughts and actions. (In James 2011:207)

Furthermore, Lukács claims that epics presented a world that was round and could be "taken in at a glance" (1971:37). It is easy to see how this becomes complicated with the emergence of Empire and, eventually, a postcolonial subject. Walcott's choice of genre ironically calls attention to the perceived fragility of Caribbean identity in comparison with Old World subjectivities (Walcott 1998: 69). While the epic often pointed to a people's settlement in their homeland and dealt with "the fate of a nation or race" (Tynan 2011: xviii), the homeland of the Caribbean subject is lost. The writing of a postcolonial epic in the face of this fact is 
metafictional as it exposes that genres such as the epic had a role in legitimising a certain worldview, one of the main tenets of Postcolonial theory. Walcott exposes such epistemic violence and dignifies the Caribbean people with this hybrid, self-referential, metafictional work which, apart from parodying the notion of absolute foundation, also claims legitimacy in Caribbean culture (Farrell 1997).

Hegel called the epic an outdated genre which had been replaced by the novel. ${ }^{1}$ Robert D. Hamner also notes that several authors and critics consider it fossilised and defunct (1997: 8). Yet, there are reasons why Walcott decided to use this form, apart from its serving as an ironic reflection on the genre's use in other cultures to express national pride. Using the genre also calls attention to the European and Asian cultural influences in the Caribbean. Walcott includes references to Anglo-Saxon writers like James Joyce as shown in these verses: "Anna Livia! Muse of our age's Omeros, undimmed Master/ and true tenor of the place!" (Walcott 1990: 200). Despite the fact that Walcott's suggestion that European colonial culture has influenced Caribbean cultural identity has often been criticised (McGarrity 2015: 21), an epic tracing the routes of Saint Lucian history cannot deny the cultural consequences - in the form of historical traces - of colonialism's "civilising" mission. The opening of the epic nonetheless quickly mentions the indigenous population of Saint Lucia - the Arawak - who were later replaced with the arrival of another tribe, the Carib (21), who were then decimated after the arrival of the Europeans:

Although the smoke forgets the earth from which it ascends, and nettles guard the holes where the laurels were killed, an iguana hears the axes, clouding each lens

over its lost name, when the hunched island was called

"Iounalao," "Where the iguana is found."

But, taking its own time, the iguana will scale

the rigging of vines in a year, its dewlap fanned, its elbows akimbo, its deliberate tail

moving with the island. The slit pods of its eyes

ripened in a pause that lasted for centuries, that rose with the Aruacs' smoke till a new race unknown to the lizard stood measuring the trees. (Walcott 1990: 4-5)

Jeremy Ingalls points out that it is actually in such conditions - "many peoples and coming in transit through many languages"- that the epic occurs (in Hamner 1997: 31). The inclusion of local forms of speech sheds light upon the fact that the Caribbean cannot be thought of without considering merging and heterogeneity. When Walcott talks about the "language [the tribe] had uttered as one nation" 
(1990: 6), it is not clear to which tribe he refers - intentionally. Although he makes repeated reference to the Arawak, the earliest settlers of his island who came from South America, he then refers to the "Aruacs' patois", patois or patwa being a French-based creole originating from the French colonisation of Saint Lucia in the seventeenth century (McGarrity 2015: 22).

Acknowledging the cultural influences of colonialism is not the same as sticking to Western epistemology. Postcolonial studies, according to Boehmer, strategically take a poststructuralist approach to language as "indeterminate, multi-layered, and historically contingent to explore how anti-colonial resistance might work in texts" (1995: 173). This is mostly perceived in the conception of history, whose manifestation in Omeros I will analyse in the following sections. It is Postmodernism as a poetics which takes its stand against traditional conventions of history in the most self-referential way, while at the same time the poststructuralist take on signification may also be illustrative, as it has been for understanding Walcott's use of the epic genre.

\section{Poststructuralism and the Sea-Voyage: Challenging the Colonial Freezing of the Past}

Omeros's flashbacks and symbolic journeys to the past express the need to reconsider the history that has been told. According to Zargarzadeh, the characters of this epic have different attitudes towards the past, either mourning the imminent oblivion of their roots, or forgetting them (2017: 716). This work concludes that for a population as fragmented as that of the Caribbean, the approach to history as something stable is not significant since, according to Hall, Africa as a place of roots or homecoming does not exist for Afro-Caribbean people as something tangible but as something eternally deferred (1989: 231). Jacques Derrida, one of the most influential philosophers articulating Poststructuralism, opposed the idea of the absolute origin to that of the trace, "a passage through the imprint” (1997: 61). Édouard Glissant explains that when arriving in the Caribbean islands, the Europeans imposed the idea or linearity. As with Christianity, but replacing Christ with Columbus, everything became conceptualised in terms of before and after the foundational figure (1997: 48). Furthermore, he explains that "[i]n the Western world the hidden cause (the consequence) of both Myth and Epic is filiation" (47). Glissant's association of filiation with the epic genre demonstrates again that Walcott's choice of genre is not a coincidence. However, this is not an epic of absolute origins but of traces. The epic makes this clear with Achille's final decision to raise Helen's child not knowing whether he is the biological father. 
Derrida destabilises the idea of origin with his definition of traces as not pointing to something essential in the "real" world and within a specific time period. There is no source of identification outside the self. Traces are constituted as chains of differences that continuously appear within signification (1997: 65). In other words:

The trace is not only the disappearance of origin - within the discourse that we sustain and according to the path that we follow it means that the origin did not even disappear, that it was never constituted except reciprocally by a nonorigin, the trace, which thus becomes the origin of the origin. (61)

All the travels described in Omeros are a reverse tracing of traces to explore what constitutes the becoming-identity of the characters through these differences with their ancestors, colonisers, and contemporaries. According to Stuart Hall, for these dispossessed communities that have lost their original homeland, cultural identity is related to discovering their Caribbeanness within the workings of culture, history, and power (1989: 225). Walcott claims in "The Antilles" that the reassembling of lost fragments of the past and the exploration of roots (and routes) have created a powerful identity since these are conscious processes which do not take a particular essentialised cultural identity for granted (1998: 69). On the contrary, detractors of this poetry of the New World and advocates of the colonial order negotiate their past and cultural identity as if it were a myth, accepting fixed definitions of their origins and their identities (37). Dispossessed communities, on the other hand, have a say in what they are defined by: "Deprived of their original language, the captured and indentured tribes create their own" (70).

Hall explains:

We must not collude with the West which, precisely, normalises and appropriates Africa by freezing it into some timeless zone of the primitive, unchanging past. Africa must at last be reckoned with by Caribbean people, but it cannot in any simple sense be merely recovered. (1989: 231)

The Western perception of the past as "unchanging" would prevent Afro-Caribbean people from identifying with a history. Though writing a community's neglected history — as Major Plunkett, non-coincidentally an English character, intends to- is also partly necessary because the notion of an unchanging past distorts and fossilises events (Walcott 1998: 36-37), it is important to continuously rethink the past according to the historical process. As Walter Benjamin's thought suggests, the way we see the past changes as the present situation from which it is perceived does (2003).

This absolute, essentialised past is symbolised in Walcott's essays, his poems, and in Omeros with the trope of ruins. Ruins are the remnants of the past, a past defined by a history appropriated by the Western world and made unchangeable 
(Walcott 1998: 41). As Walcott put it in his Nobel Prize acceptance speech, "[ $t]$ he sigh of History rises over ruins, not over landscapes, and in the Antilles there are few ruins to sigh over" (1998: 68). This idea is portrayed in Omeros when the narrator reflects on the fact that art has been appropriated by — and symbolises- a static notion of history, leaving its signs all over the globe: "Art has surrendered/ to History with its whiff of formaldehyde./ [...] Art is immortal and weighs heavily on us,/ and museums leave us at a loss for words./ Outside becomes a museum..." (Walcott 1990: 182, 183). The Caribbean, free of ruins, becomes this place in which a new culture that is able to reinterpret the frozen past can arise, since this view of the past "denies the essentialism of a prior given original or originary culture [and] all forms of culture are continually in a process of hybridity" (Bhabha 1990: 210, emphasis added).

The opposite of these ruins is the sea which, according to Tynan, is witness to all the events of the past and the transformations that took place in the course of history (2011: xiii), but it is not static like the ruins. Walcott changes the figure of the Greek Homer, whose native Greece is an example of a multitude of ruins, for Omeros, "the poet of the Seven Seas" (Tynan 2011: xvii), allowing a more flexible approach not only to the analysis of Caribbean history but of European history as well. The sea is able to wash the islands clean in "a continuous process of erasure and re-inscription" (xxi). No wonder that the mythical figure of the bard blends with one of the characters who is given the name of Seven Seas. The several sea-journeys dramatised in Omeros are undertaken by characters who wish to explore history and power relations in order to understand themselves in relation to them. Walcott suggests that history has been appropriated by the Western world in textbooks and historiography and expresses the need for a history that is not written according to Western paradigms (1998: 41, 46). Acknowledging and investigating how fragmentation and displacement have become Caribbean history establishes a powerful postcolonial identity for Omeros's characters. Nevertheless, they need to go through a long yearning to achieve a firm sense of identity.

There is a particularly significant part of the epic — which may stand as its climaxthat best represents this Derridean approach to the past. Book Three opens with the fisherman Achille being transported to a past Africa by a sea swift, a symbol of hybridity and crossbreeding (Tynan 2011: xv). God reminds Achille that it was $\mathrm{He}$ who sent the sea swift, indicating the island's religious acculturation. Achille has been acculturated and cannot remember "the name/ of the river- and the tree-god in which he steered" (Walcott 1990: 134). Neither is he able to speak his ancestors' language or even to recall the meaning of his name. Afolabe, whom he recognises as his father (136), has also been forgotten. Achille says that "Everything was forgotten. You also. I do not know./ The deaf sea has changed around every 
name that you gave/ us; trees, men, we yearn for a sound that is missing" (137). Achille recognises the erasure of identity process which people of African descent have gone through. His reflections are intertwined with references to culturally diverse - both European and African- works like the Aeneid, Shakespeare's Hamlet, and Tutuola's work on Yoruban culture (McGarrity 2015: 100) which represent the influence of the coloniser's culture on Achille's frames of reference. Furthermore, at the beginning of Book Three, it is said that all the connections Achille had with Africa were "the African movies/ he had yelped at in childhood" (Walcott 1990: 133). In conclusion, after the trip, Achille achieves a firm grasp of the idea of the trace as something inherent to his historical identity.

Afolabe relates that there has been a loss in meaning and therefore in identity to which Achille responds that "In the world I come from/ we accept the sounds we were given" (Walcott 1990: 138), alluding to the coloniser's perceived superiority. His replacement of the idea of loss with acceptance acknowledges transformation as an inherent part of all culture-forming and history. Hall explains that the original Africa from which the slaves came does not exist anymore, but that this imagined Africa that works as a metaphor for a consciously reconstructed identity is what counts (1989: 231). In terms of negotiating identity, this epic aligns with Hall's idea that identification is not a matter of common attributes, history or ancestry in essentialist terms, but always a question of Derridean différance (Hall 1996: 2-3). The ending of this ancestor-descent encounter is ambiguous. To Afolabe's reproaches that his son has forgotten many things about his ancestry, Achille responds by alluding to the symbolism of the sea swift bringing him to Africa and reconnecting him with his roots, suggesting that something of Africa is still in him, even if he does not wish to recover his lost tribal language. Afolabe still mourns this loss and claims that Achille is "only the ghost of a name" (Walcott 1990: 139). His final two questions are cryptic: "Why haven't I missed you, my son, until you were lost?/ Are you the smoke from a fire that never burned?" (139). The amalgamation of these two positions regarding lost heritage - accepting the loss and being unable to forget the past - seems to be necessary for the creation of a postcolonial identity. Walcott explains in "The Muse of History" that New World literature does not treat the past as something which defines subjects. New World poets refuse to be chained to historical fact, since the more one clings to facts, the more unchangeable history becomes. History must be formed by presences (1998: 37), something which Stuart Hall and Derrida discuss - though the latter calls them absences. Hall, using Aimé Césaire's term, refers to the Presence Africaine. Africa is present everywhere in the Caribbean, he claims, in the way the dominant language, religion, and cultural practices become modified (Hall 1989: 230), subject to transformations. To account for these transformations, Achille and other characters 
must be aware that there had been certain repressed aspects in their history. Part of the oblivion shown in Omeros is not only due to the characters' inability to trace their roots, but also because of the ongoing repression of their race. The cure for Philoctete's wound which Ma Kilman has forgotten is something her grandmother used to know: "It have a flower somewhere, a medicine, and ways / my grandmother would boil it" (Walcott 1990: 19). This indicates that some voices continue to be silenced, as is shown in one of the last chapters of the book in which it is claimed that the children at the local school continue to be told the myths and ruins of this appropriated history: "School-texts rustle to the oval portrait of a/ cloud-wigged Rodney, but the builders' names are not there,/ not Hector's ancestor's, Philoctete's, nor Achille's" (315).

Another example of silencing ethnic voices is the treatment of religion. During the narrator's descent into the underworld, he encounters Hector who purportedly is there because of his embracing of Christianity. His punishment is justified in the book by the claim that the God he worshipped was "the One that gathered his race/ in the shoal of a net" (Walcott 1990: 292). This claim highlights the necessity to be informed about the strategies of power that were used during Empire to repress certain voices. However, as Hamner points out, Omeros does not show a total embracing of tribal religion either. Instead, in Achille's attempt to blend the African traditions that he learns through his experience in the New World, the "Africanized Catholicism makes [the characters] respect not only living creatures but also the ancestral ghosts of Aruac and Carib tribesmen" (Hamner 1997: 37). Caribbean identity is thus characterised by a multiplicity which renders homage to those whose voices cannot be heard anymore. It is Ma Kilman who voices reflections about religion but, from early in the poem, it is claimed that the African tongue sounds to her as strange as Greek: "But his [Seven Seas'] words were not clear./ They were Greek to her. Or old African babble" (Walcott 1990: 19). Ironically, it is she who eventually heals the racial wound, but only after reconnecting with her roots, as the Yoruban gods explain to her how to find the herbal remedy. Repetition with regard to tradition is present in Omeros, but it is a repetition with a difference (Tynan 2011: 146-147), in accordance with Derridean and Deleuzian theory.

This ambiguous reclaiming of annihilated cultures together with the celebration of characters who have forgotten or readapted them under the influence of colonialism in the creation of a hybrid culture is portrayed in this work using postmodernist literary techniques such as intertextuality, multiple voices, parody, pastiche, and metafictional reflections on historiography. As explained in the introduction, Postmodernism should not be treated as a cultural movement exclusively pertaining to the West because of the effects of globalisation which are also referred to in 
some of the voyages described in the epic. Such voyages are not only those of Achille to the tribe of his ancestors or through the Middle Passage, but also the contemporary migration of the narrator to the United States, all mixed and intermingled defying traditional historiography and linear storytelling. Elleke Boehmer explains that an unprecedented demographic change took place after decolonisation and has thus become something quite characteristic of postcolonial populations (1995: 233). She makes reference to Homi Bhabha's notion of the postcolonial text as hybrid in claiming that "the migrant text is that hybridity writ large and in colour" (234). It is a consideration of the postmodern world on the part of Walcott to use the diasporic experience of a character (the narrator) and the so-called "transnational aesthetic" (234) to articulate the postcolonial. The next section will explore the postmodern poetics identifiable in this epic and the purposes which Postmodernism may serve. Considering Omeros a postmodern text adds valuable insights to the previous analysis of its poststructuralist characteristics with regard to the treatment of history and the past.

\section{Omeros as a Postmodern Text}

As with the previous consideration of Derridean différance in the analysis of the poem, if we look at it through Linda Hutcheon's theory of Postmodernism and historiographic metafiction, it becomes apparent that this epic reconsiders the way the past has been told and that history is a particular way of making fiction (White 1978: 122). According to Hutcheon, postmodern theory and art stress the fact that both fiction and history are "linguistic constructs, highly conventionalized in their narrative forms, and not at all transparent" (1988: 105). If "Postmodern fiction suggests that to re-write or to re-present the past in fiction and in history is, in both cases, to open it up to the present, to prevent it from being conclusive and teleological" (110), we can conclude that Achille's voyage to his ancestors' land in Book Three, for example, is part of a postmodernist poetics of re-interpreting the past. Perhaps most interesting from the point of view of this article is Hutcheon's belief that Postmodernism's deconstruction of grand narratives like history results in an "ideological awareness" of "political, social, and linguistic repression" (181), becoming relevant for the articulation of postcolonial theories. By analysing several aspects of this epic, one can conclude that it is a postmodern work we are dealing with.

By way of introduction to Postmodernism, Hutcheon explains that:

the postmodern's initial concern is to de-naturalize some of the dominant features of our way of life; to point out that those entities that we unthinkingly experience as 'natural' (they might even include capitalism, patriarchy, liberal humanism) are in fact 'cultural'; made by us, not given to us. (1989: 2) 


\section{Defying Absolutes and Essentialism in Derek Walcott's Omeros}

Jean-François Lyotard terms these dominant discourses that become challenged 'metanarratives', and defines Postmodernism as the distrust of such narratives (1985). From these definitions one can conclude that Postmodernism becomes a valuable tool for the once colonised since it was these metanarratives that perpetuated the oppression and silence of certain population groups or racial minorities. Apart from the playful subversion of the epic genre already analysed, other worth mentioning formal features in Walcott's work which serve to challenge the metanarratives defined by Lyotard are self-referentiality, metafiction, parody, pastiche, or intertextuality.

Hutcheon reminds readers of Walter Benjamin's famous text "The Work of Art in the Age of Mechanical Reproduction" (1935) when she describes the pastiche of fragments of history and/or information that many postmodernist novels are, claiming that "the aura of the original, genuine, single work of genius is [gone]" (Hutcheon 1988: 181). This is of great relevance to the previously mentioned debate on Walcott's use of a canonical genre, in this case the epic. Walcott's own essay, "The Caribbean: Culture or Mimicry?", which borrows Naipaul's notion of 'mimic men', the title of one of his novels, ironically reflects on this idea too. In a postmodern poststructuralist fashion, Walcott claims that "everything is mere repetition" (1974: 7), dismissing the accusations that mimicry is not creation, claiming that every creation is an act of mimicry and has always been so since the evolution of ape into man (10). With this claim Walcott asserts his poststructuralist take on all writing as a chain of differences along signification. This naturalising approach to mimicry would not be problematic but rather an assumption for Postmodernism, as it is for Walcott, who "appropriates Naipaul's dismissive apothegm that 'nothing has ever been created in the West Indies, and nothing will ever be created" (Edwards and Walcott 1996: 32) in order to claim that what the Caribbean has done is to imagine and invent more than any other nation (Walcott 1974). "Everything can only be mimicry" (8), he claims, meaning of course either everything or nothing, for a creation is "nothing one has ever seen before" (9).

Walcott's words evoke Kristeva's notion of intertextuality, that "[ $\mathrm{e}] \mathrm{ach}$ word (text) is an intersection of words (texts) where at least one other word (text) can be read" (1986: 37). Hence the metafictional parodic inclusion, among many, of a Greek character named Antigone who, reminding readers of her Greek homologue, plays the exile and, like the Saint Lucian narrator, wishes to go back to her islands: "'I'm tired of America, it's time for me to go back/ to Greece. I miss my islands.' I write, it returns-/ the way she turned and shook out the black gust of hair" (Walcott 1990: 14). The inclusion of Homeric homologues is recurrent in the poem, as when one of the Saint Lucian characters, Helen, is walking on the beach and we learn that a cloud of smoke separates her from where "white Helen [of Troy] died" 
(34). While she keeps walking, Helen sings The Beatles' Yesterday and in the next subchapter the word "yesterday" continues to be used for introducing episodes of the Trojan War, triggered by Helen's spotting of a boy on a horse (35). Not only are references to classical Greece included; the following chapter associates the fruits found at the local market with ancient empires: "Mohammedan melons", "bananas from a Pharaoh's casket", "lemons gold as the balls of Etruscan lions". The list of references is immense in Omeros.

These canonical figures - or at least characters named after them - interact with common ones. This reminds us of Bakhtin's definition of parody as "the 'absolute past' $[\ldots]$ brought low, represented on a plane equal with contemporary life, in an everyday environment, in the low language of contemporaneity" (1981:21). What we can know about history is learnt through texts like the Iliad, in accordance with a more postmodern definition of parody by Hutcheon as "an opposition or contrast between texts" (2000: 30). Hutcheon calls such knowledge traces, reminding us of Derrida's previously explored concept. Parody and intertextuality then go hand in hand because of their constant reminder that history only becomes known through textual activity, which is always interpretative and meaning-making (Hutcheon 1988: 125). This would explain Walcott's often criticised and ambiguous relationship with European culture, its discursive and textual practices being traces to understand or get to know the past. With the postmodern poetics as explained by Hutcheon, this text - with its many references to classical Greek and European traditions and texts - asserts the authority of such Western epistemology to later question it: "this, once again, is the postmodern paradox" (126).

This way of writing has been termed historiographic metafiction. Patricia Waugh defines metafiction as "fictional writing which self-consciously and systematically draws attention to its status as an artefact in order to pose questions about the relationship between fiction and reality" (1984: 2). A clear example of metafiction occurs in Book 1, Chapter V, when Major Plunkett, an English former colonial officer retired and settled in Saint Lucia, recalls in the narrative first person singular an incident in which his head was wounded during a battle in the Mediterranean. In the midst of this recollection, another "I" makes an appearance: it is the narrator who admits to writing this story:

This wound I have stitched into Plunkett's character.
He has to be wounded, affliction is one theme
of this work, this fiction, since every "I" is a
fiction finally. Phantom narrator, resume:
Tumbly. Blue holes for his eyes. And Scottie wiser
when the shock passed. Plain men. Not striking. Not handsome.

(Walcott 1990: 28, emphasis in original) 


\section{Defying Absolutes and Essentialism in Derek Walcott's Omeros}

Adding the modifier "historiographic" to the metafiction concept supposes a destabilisation of the nineteenth century belief that "historical discourse $[\ldots]$ would consist of nothing but factually accurate statements about a realm of events which were (or had been) observable in principle" and which led to an objective truth (White 1978: 123). Although this fragment only describes the conscious choice of a character's attributes, the idea of invisible control remains present throughout the whole epic. What if such decisions were taken in history writing? This first encounter of the reader with metafiction is particularly significant as a few pages later Major Plunkett decides that he will write Helen's history (Walcott 1990: 30). While, as already stated, the poststructuralist approach points to the existence of many histories, historiographic metafiction throws light on the narrative nature of all of them.

Each chapter in Omeros starts with a different time, space, and focalisation, not respecting chronological linearity, thus rejecting the unified colonialist view of the Caribbean and its inhabitants. As such, the narrator affirms that "every ' $\mathrm{I}$ ' is a fiction" (Walcott 1990: 28), not assuming that colonialist theorisations of the region are incorrect, but rather affirming that other versions would be equally valid. And, in fact, there are many different and contradicting ones combined along the poem's pages. With the presentation of multiple voices and perspectives - multiple "I"s - this work defies Bakhtin's perception of the epic as monoglossic (1981: 12). This rejection of absolute truth and monolithic history confirms the previously explained perception of the homeland in the epic as an absence rather than a presence, something experienced differently by each character. Hence the multiplicity of perspectives. Ireland for Maud, Major Plunkett's wife, is no more real than Africa for Achille. It is the very nature of the Caribbean, or Walcott's broader sense of the Americas, that is associated with the ability to take this approach, for it is the European character who wants to write an absolute history for his maid Helen: "It was at that moment that he felt a duty/towards her hopelessness, something to redress / (he punned relentlessly) that desolate beauty/ so like her island's. He drained the foaming Guinness" (Walcott 1990: 29-30). The characteristic of the Caribbean epic is that it is composed of many histories, not one foundational history. In consonance with the multiplicity of voices and perspectives, what is constant throughout the epic is the rejection of a single version of truth, history, and the homeland. Walcott made this clear with the ending of his essay "The Caribbean: Culture or Mimicry?", where the following is stated:

The New World originated in hypocrisy and genocide, so it is not a question for us, of returning to an Eden or of creating Utopia; out of the sordid and degrading beginning of the West Indies, we could only go further in decency and regret. Poets and satirists are afflicted with the superior stupidity which believes that societies can 
be renewed, and one of the most nourishing sites for such a renewal, however visionary it may seem, is the American archipelago. (1974: 13)

The postmodern work of literature, with its emphasis on intertextuality, becomes relevant in order to articulate the notions of postcolonial home and roots that Omeros's characters seem to be looking for. Postmodernism establishes the conditions required to know the past, which is never going to be absolute but discursively composed (Hutcheon 1988: 119). In this way, it is not only Achille's voyage to the mythical Africa that serves to establish roots for this community, but the global intertextual parodic elements present throughout the whole text.

\section{Conclusion}

Walcott's epic makes use of a series of theoretical, philosophical, and narrative devices in its articulation of the recovery of a lost homeland and identity. The poststructuralist and postmodern approach that the poem denotes can be a useful tool for the much desired self-representation of postcolonial peoples, in opposition to what Gayatri Spivak, following Foucault's idea of discourse (2001), has termed "epistemic violence" (Spivak 1994: 76).

The epic form of Omeros ironically reflects on the traditional role of epics in presenting foundational myths as something absolute. Walcott's epic defines the past as non-absolute because its perception is —and will continue to be- subject to many transformations, as Derrida's concept of différance illustrates. Derek Walcott's epic reconceptualises the way one should approach Caribbean history, especially because of the effects of colonialism on the identity of Caribbean descendants of African slaves: deprived of their culture, only having the coloniser's language to self-represent themselves. The postmodern parodic and poststructuralist approach to literature is the only way of articulating in this context a genre which has traditionally been used to talk about roots, homecoming, and recovery.

According to the Saint Lucian poet, there are two ways of looking at the past; as stable and frozen or as iterable and subject to transformations. Both views are addressed in Omeros through the trope of the sea - renewable, purifying- or the ruins - static, unchangeable. Most of Walcott's Caribbean characters have strong connections with the sea, as the fishermen motif or the presence of a poetic conscience named Seven Seas show. The sea metaphor stands for how cultural contact makes identity fluid and transformable.

The consideration of the postmodernist poetics of the text which includes intertextuality, parody, multiplicity of perspective, and metafiction, contributes to our understanding of Walcott's view of Caribbean identity as mobile rather than 
static. Therefore, Naipaul's accusations that Caribbean texts are mere mimicry become absurd, as such poetics defies notions of texts and other cultural productions as original works of genius. The inclusion of a metafictional narrator throws light on the fact that history is a fiction, as well as the epic, and as well as "every 'I'", in Walcott's words (1990: 28). Omeros, as a postmodern text, reflects theories of historiography, historical knowledge, and identity formation as explained by Linda Hutcheon in A Poetics of Postmodernism: history is non-absolute and only known through textual activity. The paradoxes that this approach entails explain the open ending of the text in which the characters are presented as fated to new transformations and ready to endure the unavoidable historical processes which have defined them as a people so far. ${ }^{2}$

\section{Notes}

1. Domínguez Caparrós explains how Hegel described the novel as "épica de los tiempos modernos" (2009: 164) ("the epic for modern times") and at the same time declares a modern epic impossible (James 2011: 205, 207).
2. Research for this publication was funded by MINECO through research project FFI2015-64137-P.

\section{Works Cited}

BAKHTIN, Mikhail. 1981. The Dialogic Imagination: Four Essays. Ed. M. Holquist. Trans. C. Emerson and M. Holquist. Austin: University of Texas Press.

BenJamin, Walter. 2003. "On the Concept of History". In Jennings, MichaelW. (ed.) Selected Writings. Cambridge, Mass, and London: Harvard U.P.: 389-400.

BнABHA, Homi K. 1990. "The Third Space". In Rutherford, Jonathan (ed.) Identity, Community, Culture, Difference. London: Lawrence and Wishart: 207-221.

Boenmer, Elleke. 1995. Colonial and Postcolonial Literature. Oxford: Oxford U.P.
Byers, Thomas. 2011. "The Revenant". Revista de letras 2 (51): 9-27.

CALLAHAN, Lance. 2003. In the Shadows of Divine Perfection: Derek Walcott's Omeros. New York: Routledge.

Deleuze, Gilles. 1968. Repetition and Difference. Trans. P. Patton. New York: Columbia U.P.

DerRIDA, Jacques. 1997. Of Grammatology. Trans. G.C. Spivak. Baltimore and London: Johns Hopkins U.P.

Domínguez CAPARRós, José. 2009. Introducción a la teoría literaria. Madrid: Editorial Universitaria Ramón Areces. 


\section{Mónica Fernández Jiménez}

Edwards, Norval and Derek Walcott. 1996. "The Poetics of Two Margins". Journal of Interamerican Studies and World Affairs 3 (24): 12-35.

FARRELL, Joseph. 1997. "Walcott's Omeros: The Classical Epic in a Postcolonial World". In Wofford, Suzanne, Margaret Beisinger and Jane Tylus (eds.) Epic Traditions in the Contemporary World: The Poetics of Community. Berkeley: University of California Press: 247-273.

Foucault, Michel. 2001. Madness and Civilization: A History of Insanity in the Age of Reason. Trans R. Howard. London and New York: Routledge.

GIKANDI, Simon. 2006. "Poststructuralism and Postcolonial Discourse". In Lazarus, Neil (ed.) The Cambridge Companion to Postcolonial Literary Studies. Cambridge: Cambridge U.P.: 97-119.

Glissant, Édouard. 1997. Poetics of Relation.

Michigan Press.

HaLL, Stuart. 1989. "Cultural Identity and Diaspora". Framework: Journal of Cinema and Media 36: 222-237.

HaLL, Stuart. 1996. "Introduction: Who Needs Identity?" In Hall, Stuart and Paul Du Gay (eds.) Questions of Cultural Identity. London: Sage: 2-17.

HamneR, Robert D. 1997. Epic of the Dispossessed: Derek Walcott's Omeros. Columbia: University of Missouri Press.

HоOKS, bell. 2001. "Postmodern Blackness". In Leitch, Vincent B. (ed.) The Norton Anthology of Theory and Criticism. New York and London: W.W. Norton \& Company: 25092516.

Hutcheon, Linda. 1988. A Poetics of Postmodernism: History, Theory, Fiction. London and New York: Routledge.

HutChEON, Linda. 1989. The Politics of Postmodernism. London and New York: Routledge.

Hutcheon, Linda. 2000. A Theory of Parody. Urbana and Chicago: University of Illinois Press.

James, David. 2011. "Civil Society and Literature: Hegel and Lukács on the Possibility of a Modern Epic". The European Legacy 2 (16): 205-221.

JAY, Paul. 2006. "Fated to Unoriginality: The Politics of Mimicry in Derek Walcott's Omeros". Callaloo 2 (29): 545-559.

Kristeva, Julia. 1986. The Kristeva Reader. New York: Columbia U.P.

LoombA, Ania. 1998. Colonialism/ Postcolonialism. London and New York: Routledge.

LUKÁCs, Georg. 1971. The Theory of the Novel: A Historico-Philosophical Essay on the Forms of the Great Epic Literature. Trans. A. Bostock. London: Merlin Press.

LyotARD, Jean-François. 1985. The Postmodern Condition: A Report on Knowledge. Trans. G. Bennington and B. Massumi. Minneapolis: University of Minnesota Press.

McGarrity, Maria. 2015. Allusions in Omeros: Notes and a Guide to Derek Walcott's Masterpiece. Gainesville: University Press of Florida.

Prakash, Gyan. 1994. "Subaltern Studies as Postcolonial Criticism". The American Historical Review 5 (99): 1475-1490.

SPIVAK, Gayatri Chakravorty. 1994. "Can the Subaltern Speak?" In Williams, Patrick and Laura Chrisman (eds.) Colonial Discourse and Post-Colonial Theory: A Reader. New York: Columbia U.P.: 66-111.

TeradA, Rei. 1992. Derek Walcott's Poetry: American Mimicry. Boston: Northeastern U.P.

TоOHEY, Peter. 1992. Reading Epic: An Introduction to the Ancient Narratives. London: Routledge.

Tynan, Maeve. 2011. Postcolonial Odysseys: Derek Walcott's Voyages of Homecoming. Newcastle upon Tyne: Cambridge Scholars Publishing.

WALCOTT, Derek. 1974. "The Caribbean: Culture or Mimicry?" Journal of Interamerican Studies and World Affairs 1 (16): 3-13.

Walcott, Derek. 1990. Omeros. New York: Farrar, Straus and Giroux. 
WALCOTT, Derek. 1998. What the Twilight Says. New York: Farrar, Straus and Giroux.

WalcotT, Derek. 2014. The Poetry of Derek Walcott: 1948-2013. Selected by G. Maxwell. New York: Farrar, Straus and Giroux.

WAUGH, Patricia. 1984. Metafiction: The Theory and Practice of Self-Conscious Fiction. London and New York: Routledge.
WHITE, Hayden. 1978. Tropics of Discourse: Essays in Cultural Criticism. Baltimore and London:The John Hopkins U.P.

ZARGARZADEH, Haleh. 2017. “Rhiz(h)oming Achille: Walcott, Glissant, and the Politics of Relation and Creolization". Journal of Postcolonial Writing 6 (53): 715-728.

Received: $28 / 03 / 2019$

Accepted: 02/10/2019 